\title{
THE RISE OF SMALLER CITIES AND ITS MEANING IN INTERNATIONAL TOURISM TO JAPAN
}

\author{
KoJI KITADA \\ Chukyo University, Nagoya, Japan \\ Manuscript received August 5, 2011 \\ Revised version October 26, 2011
}

\begin{abstract}
KITADA K., The rise of smaller cities and its meaning in international tourism to Japan. Quaestiones Geographicae 30(4), Bogucki Wydawnictwo Naukowe, Poznań 2011, pp. 69-80, 2 figs, 9 photos, 9 tables. DOI 10.2478/v10117011-0040-y, ISBN 978-83-62662-88-3, ISSN 0137-477X.
\end{abstract}

ABSTRACT. The number of foreign tourists visiting Japan has steadily increased in the recent decades. The country has much variety between districts in spite of its small area, and there is a close relation between the variety of tourist resources and preferences of foreign visitors according to their nationalities. For example, prefectures located in the Hokuriku and Hida district, which do not have large cities, have shown a rapid increase in foreign visitors in the recent years and become one of the major international tourist areas in Japan. The district is mainly supported by visitors from Taiwan and Europe seeking tradition of Japan in smaller cities and the beauty of nature. It is true that $75 \%$ of foreign tourists visiting Japan come from Asia and many of them prefer shopping in large cities. But it is also important to enhance historic and cultural value of tourist resources to heighten the attraction of Japan: variety between districts.

KEY WORDS: Japan, international tourism, foreign tourists, Hokuriku and Hida district

Koji Kitada, Chukyo University, 101-2 Yagoto Honmachi, Showa-ku, Nagoya-shi, 466-8666, Japan; e-mail: miikun-kitada@ muh.biglobe.ne.jp

\section{Introduction}

The number of foreign tourists visiting Japan was about 6.05 million in 2008. It is still much smaller than that in Western countries such as France, Spain, Italy or the USA. But foreign visitors to Japan have increased steadily in the recent decades and will increase further in the future despite the serious damage by the earthquake and tsunami which attacked the north-east part of the country on March 11, 2011. Following this tendency, also studies of tourism to Japan have seen a great increase, especially in the first decade of the $21^{\text {st }}$ century. For example, in Jinbunchiri
(Human geography), which is one of the major geographical journals in Japan, a new column was set up in 2007 to review geographical theses or books about tourism every year following other geographical studies. Among them, one of the most remarkable is that edited by Kanda (2009), written by young Japanese geographers and analysing tourism to Japan from various sides.

But in spite of that, most of the studies about tourism to Japan deal with domestic visitors or entities preparing for tourists, such as self-governing bodies, enterprises, and national government. Studies focusing on tourists themselves, especially foreign tourists visiting Japan, are still 
Table 1. Ranking of Japanese prefectures by the number of foreign visitors (2010).

\begin{tabular}{|c|c|}
\hline $\begin{array}{l}\text { Ranking of prefectures and } \\
\text { ratio of foreign visitors they } \\
\text { receive }(\%)\end{array}$ & $\begin{array}{l}\text { Change in rank be- } \\
\text { tween } 1997 \text { and } 2010\end{array}$ \\
\hline 1. • Tokyo $(60.3)$ & No change \\
\hline 2. $\circ$ Osaka (26.1) & No change \\
\hline 3. $\circ \quad$ Kyoto $(24.0)$ & +2 \\
\hline 4. • Kanagawa (17.8) & No change \\
\hline 5. $・$ Chiba (15.0) & -2 \\
\hline 6. $\quad$ Aichi (10.9) & No change \\
\hline 7. a Fukuoka (9.1) & No change \\
\hline 8. $\quad$ Hokkaido $(8.8)$ & +9 \\
\hline 9. - Yamanashi (8.2) & +3 \\
\hline 10. $\circ$ Hyogo (7.6) & -1 \\
\hline 11. $\circ \quad$ Nara (7.5) & +1 \\
\hline 12. - Oita (5.0) & +3 \\
\hline 13. Kumamoto (4.3) & No change \\
\hline 14. Hiroshima (4.1) & +2 \\
\hline 15. • Tochigi (3.6) & +4 \\
\hline
\end{tabular}

Source: homepage of JNTO (Japan National Tourism Organization). Sample investigation at main international airports and ports in Japan (sample size 21,342). The prefectures are located in: • Kanto district (Tokyo metropolitan area), o Kinki district (Keihanshin metropolitan area) and $\mathbf{\square}$ Kyushu district.

very few with rare exceptions, such as Shimizu (2007), Ohyabu \& Ohuchi (2008), and Matsumura (2009). The main reasons are as follows: the number of foreign tourists to Japan is still small and they do not have enough importance for the economy yet; Japan is an island country and has had no experience of receiving so many tourists from foreign countries like European countries until now; and recently the Japanese do not have enough interest in travelling abroad because of the current economic decline.

But if we want to develop international tourism and make it one of the important industries in the future, we have to consider international tourism to Japan from a wider point of view. First, we must not forget that in spite of its relatively small area, Japan has much variety, from a sub-Arctic climate in the north to a subtropical climate in the south, and from large cities to small villages. Also, we cannot approach foreign tourists in a simple way, because they vary greatly by nationality and preferences. It means that there is much difference in the districts visited by foreign tourists according to their preferences. Also, we have to regard visitors not only as a means of using money, but as the most important subject in international tourism. In this study, we inves- tigate the variety of preferences among foreign tourists according to their nationality, and how they relate to the tourist resources of the districts they visit.

The basic structure of international tourism to Japan has not changed much over the recent decades in spite of the relative increase in the number of visitors. As is shown in Table 1, the top-ranking prefectures are almost the same: Tokyo, Kyoto and Osaka, with the only exception of Hokkaido, which improved its ranking from $17^{\text {th }}$ in 1997 to $8^{\text {th }}$ in 2010, especially in the first decade of the $21^{\text {st }}$ century.

But we also have to know that a little but important change is occurring. Some prefectures, such as Toyama, Ishikawa and Gifu, have improved their ranking remarkably in the number of foreign visitors in the recent decades and now occupy a middle rank among the total of 47 prefectures in Japan (their locations are shown in Fig. 1). They showed the highest growth in the ranking of all prefectures. For example, between 1977 and 2010 Toyama Prefecture rose from 37th to $27^{\text {th }}$ position, Ishikawa Prefecture from $31^{\text {st }}$ to $21^{\text {st }}$, and Gifu Prefecture from $25^{\text {th }}$ to $16^{\text {th }}$. And the change occurred in only about five years. Moreover, these prefectures are adjacent to each other. We can see no other prefectures like that. Toyama and Ishikawa belong to the Hokuriku district

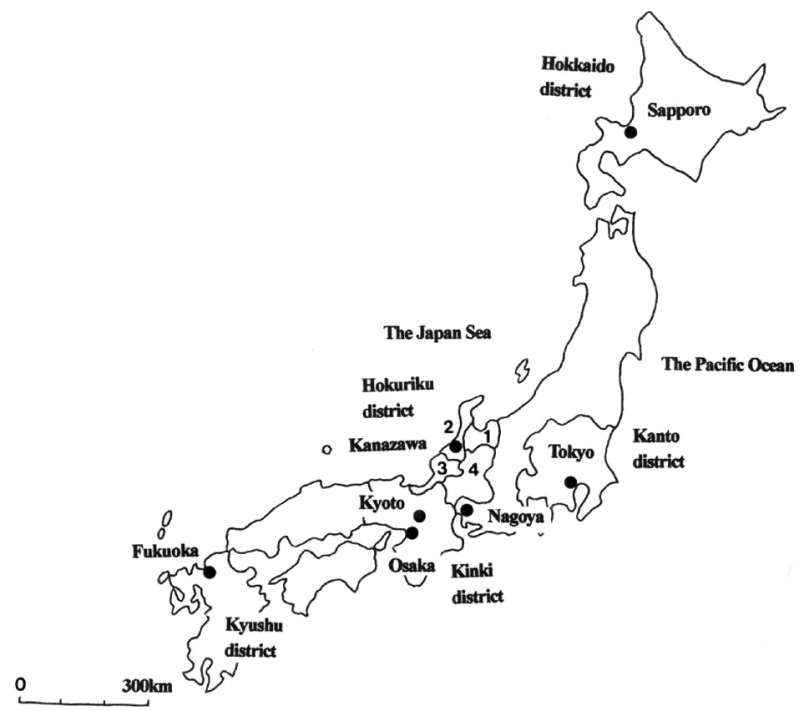

Fig. 1. Location of Toyama, Ishikawa, Fukui, and Gifu Prefectures and other major cities and districts in Japan

1. Toyama Prefecture, 2. Ishikawa Prefecture, 3. Fukui Prefecture,

4. Gifu Prefecture. Okinawa Prefecture, located at the southwest end of Japan, is excluded here. 
with Fukui Prefecture. Strictly speaking, Gifu Prefecture is not part of the Hokuriku district, but most of the popular tourist spots in this prefecture, such as Takayama and Shirakawago, are located in its northern part called the Hida district, which is adjacent to the Hokuriku district. The climate of the Hida district with its heavy snow in winter also bears much resemblance to that of the Hokuriku district. Therefore, in this study, we use the phrase 'the Hokuriku and Hida district' for the sake of convenience.

We mainly deal with the rapid increase in foreign tourists to the Hokuriku and Hida district and its background by focusing on the relationship between preferences of the tourists by nationality and tourist resources offered by the district. We also analyse the meaning of the rise of this district in international tourism to Japan.

\section{The character of tourist resources in the Hokuriku and Hida district}

The Hokuriku and Hida district is located in the central part of Japan between the Sea of Japan and the Central Mountains, more than 3,000 $\mathrm{m}$ in height. It takes about 3 hours by limited express from Osaka or Nagoya to Kanazawa, the capital of Ishikawa Prefecture, and 2.5 hours from Kyoto. In winter, this district is famous for the heaviest snow in Japan, but it is not so cold as in other districts, like Hokkaido located in the northern end of the country. The temperature in summer is almost equal to that in other major cities, like Tokyo and Osaka.

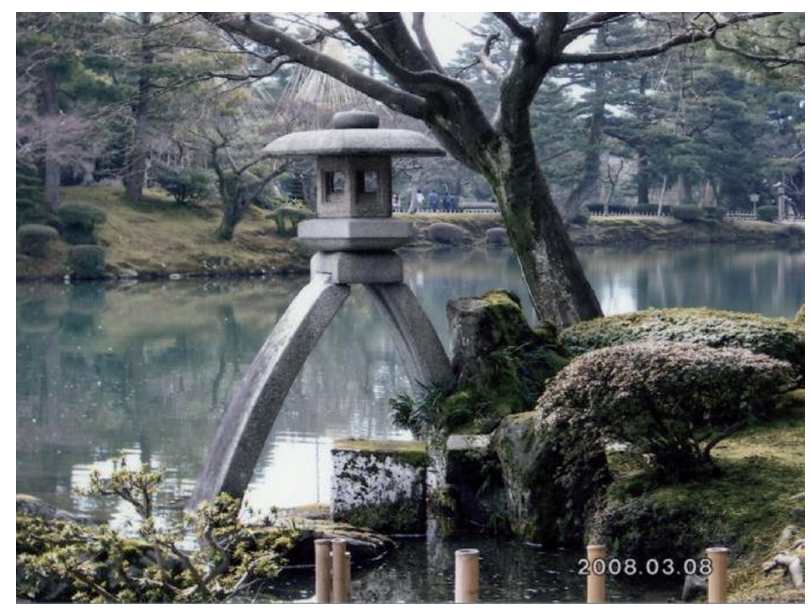

Photo 1. The Kenrokuen garden in Kanazawa.
The population of the Hokuriku and Hida district is about 322.7 million (according to the 2010 national census) and accounts for about $2.5 \%$ of the total population in Japan. There are no cities with a population of more than 1 mil-

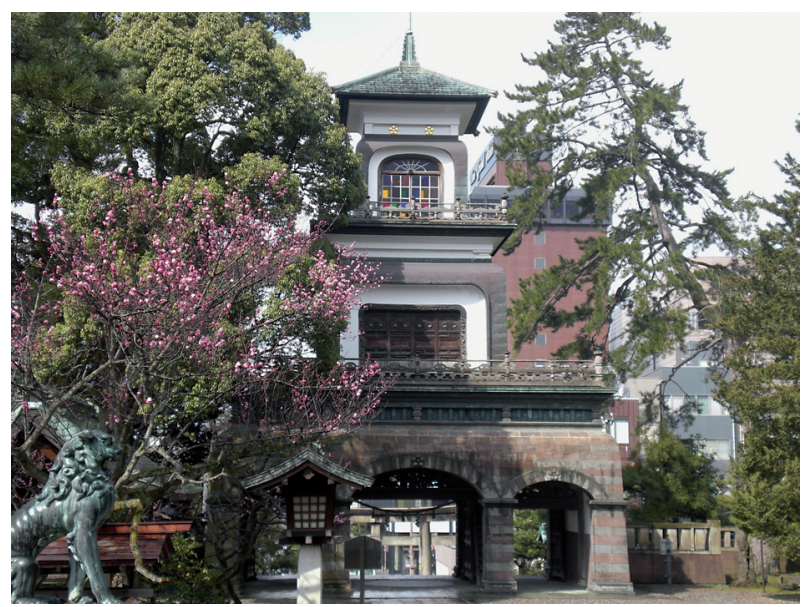

Photo 2. The gate of the Oyama shrine in Kanazawa.

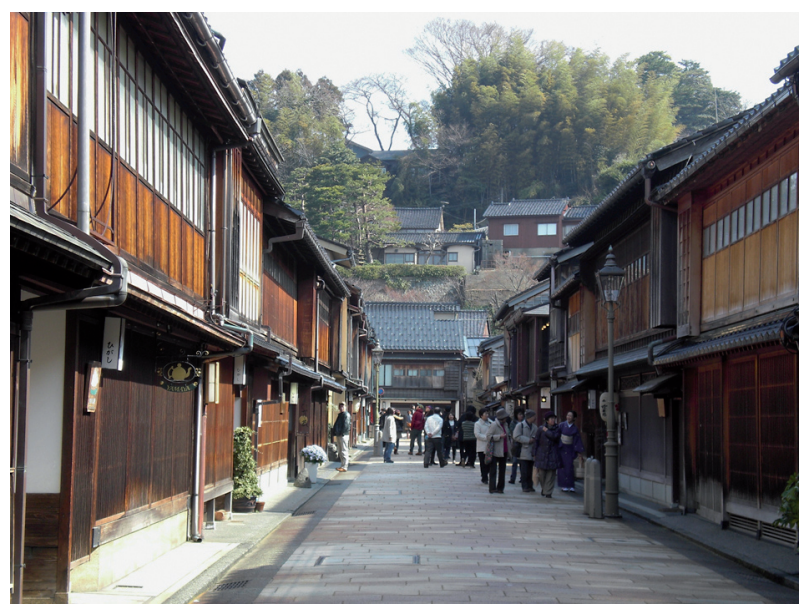

Photo 3. Higashichaya Street in Kanazawa.

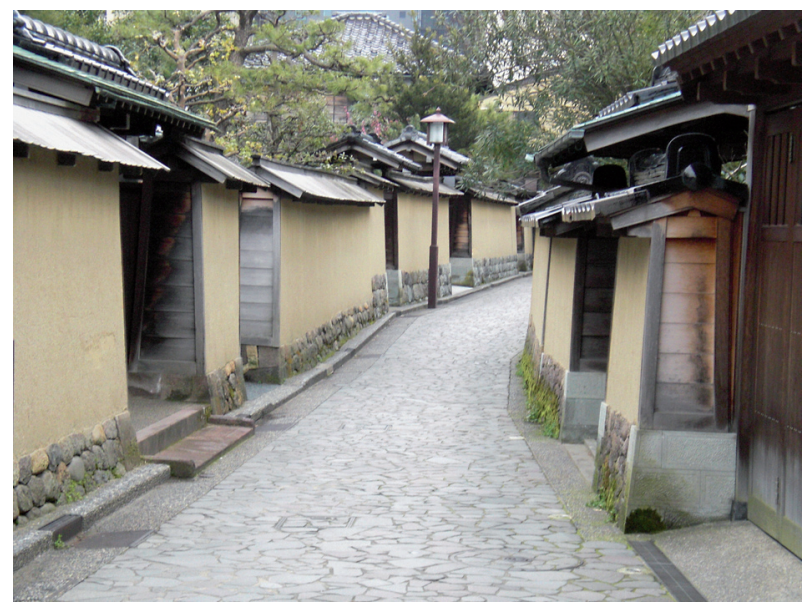

Photo 4. Traditional houses of samurai in Kanazawa. 


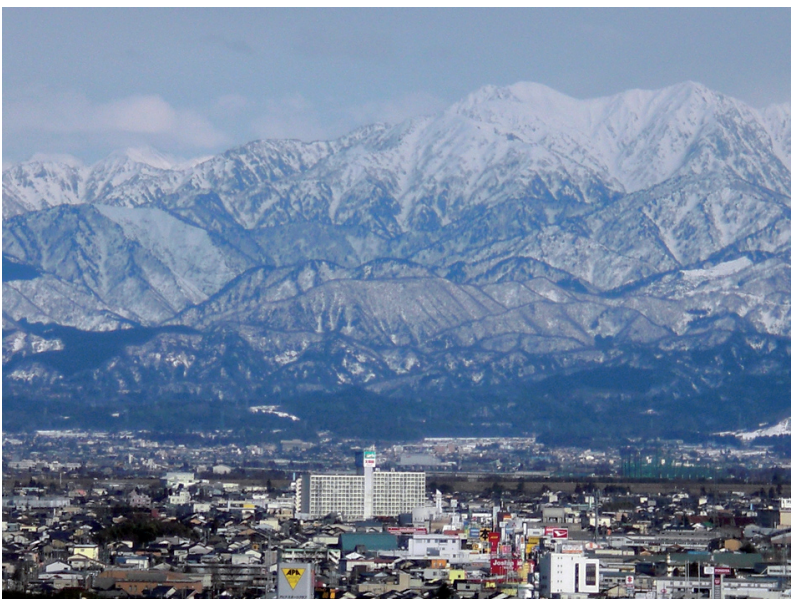

Photo 5. The Tateyama Mountains from the city hall of Toyama.

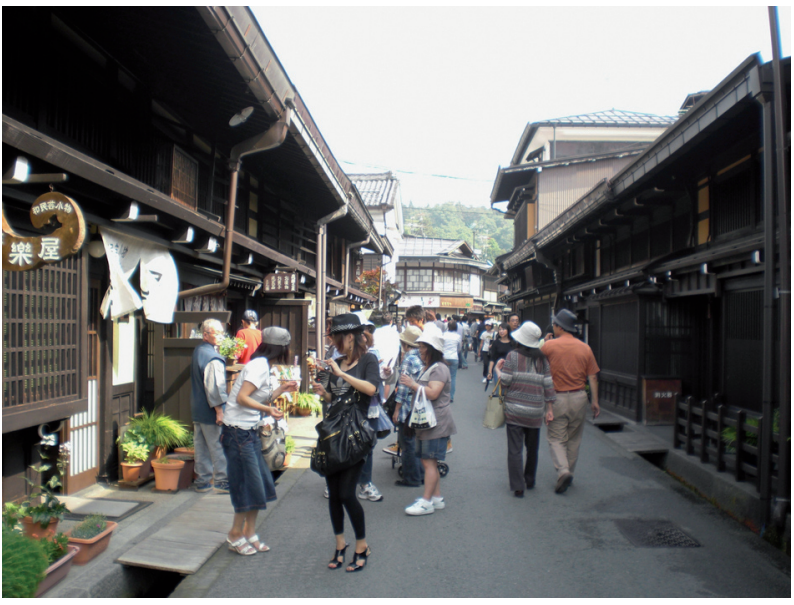

Photo 6. A street in the downtown of Takayama.

lion. Even Kanazawa, the largest town in the district, had only 462,000 residents in 2010. But the beauty of nature changing with the season in the Hokuriku and Hida district, such as cherry blossom in spring, maple leaves in autumn, and heavy snow in winter, has long been highly appreciated. There are also many hot springs and mountain peaks which attract not only mountain climbers but also ordinary tourists using the cable car and the ropeway, such as the alpine route of Tateyama and Kurobe. Also, there are many medium-sized or small towns, such as Kanazawa and Takayama, famous for maintaining the atmosphere of Japan in the good old days and for excellent handicrafts. The latter is the largest town in the Hida district with a population of about 93,000 in 2010.

As has been mentioned, the main tourist resources in the Hokuriku and Hida district are the beauty of nature changing with the season, mountains, hot springs, and medium-sized or small towns with the tradition of the good old days of Japan. As for tourist spots, here are some photos (all the photos taken by the author).

\section{Preferences of foreign visitors by nationality and their relationship with tourist resources in the Hokuriku and Hida district}

In this chapter, we mainly analyse the relationship between preferences of foreign visitors and the tourist resources of the Hokuriku and Hida district. At first, we examine the composition of the tourists by nationality. Table 2 shows this in Toyama, Ishikawa, Fukui and Gifu Prefectures in 2008.

The largest number of foreign tourists visiting the Hokuriku and Hida district come from Taiwan. They are the second largest group visiting Japan. And the proportion of Taiwanese tourists to prefectures located in the Hokuriku and Hida district is even higher than for the whole of Japan. The proportion of tourists from western countries, such as the USA, Canada, the UK, France, and Germany, is also high. The proportion of visitors from European countries to Ishikawa and Gifu Prefectures is much higher than the figure for Japan as a whole. This means that the proportion of tourists from Taiwan and Europe to the Hokuriku and Hida district is much higher than for the whole of Japan in spite of them being a minority in terms of numbers (especially Europeans).

Next we investigate the concrete destinations of foreign visitors to the Hokuriku and Hida district by nationality. Table 3 shows data on tourists from Taiwan, who contribute the bulk of visitors to the district. We especially focus on package tours because a lot of Asian tourists travel abroad in this way, unlike those from western countries, who mostly come on an individual basis. For example, $37.9 \%$ of tourists from South Korea and $52.3 \%$ of those from Taiwan come on package tours in the strict sense of the word, with a professional guide and prearranged hotels and tourist destinations (JNTO 2009). Guidebooks in Asia 
Table 2. Composition of foreign tourists by nationality in Toyama, Ishikawa, Fukui, and Gifu prefectures in $2008(\%)$.

\begin{tabular}{|c|c|c|c|c|c|}
\hline \multirow{2}{*}{ Prefecture } & \multicolumn{5}{|c|}{ Nationality } \\
\cline { 2 - 6 } & South Korea & Taiwan & China & USA and Canada & $\begin{array}{c}\text { UK, France and } \\
\text { Germany }\end{array}$ \\
\hline Toyama & 16.3 & $\mathbf{5 1 . 1 ^ { * }}$ & 2.8 & 6.4 & 2.8 \\
\hline Ishikawa & 5.3 & $\mathbf{3 0 . 7 ^ { * }}$ & 4.2 & 15.9 & $\mathbf{1 3 . 7}^{*}$ \\
\hline Fukui & 15.0 & $\mathbf{3 7 . 5 ^ { * }}$ & 10.0 & 7.5 & 5.0 \\
\hline Gifu & 9.7 & $\mathbf{3 0 . 6 ^ { * }}$ & 5.7 & 12.2 & $\mathbf{1 1 . 4}$ \\
\hline JAPAN & 27.0 & 17.4 & 9.9 & 13.0 & 7.5 \\
\hline
\end{tabular}

Source: JNTO (2009). The USA and Canada as well as the UK, France and Germany are summed up together. * - means that the proportion is more than 1.5 times that of tourists of this nationality in the whole of Japan. Data from a sample investigation at main international airports and ports in Japan (sample size 14,963).

often offer too much information and it is very difficult for an individual to distinguish unique tourist spots from ordinary ones.

Table 3 shows data on package tours from Taiwan to the Hokuriku and Hida district in March and April 2011 when they can enjoy both the cherry blossom in towns such as Kanazawa and a snow landscape in the mountain area along the alpine route of Tateyama and Kurobe. Many of them were cancelled after the disastrous earthquake Japan suffered on 11 March this year, but

Table 3. Main tourist spots in the Hokuriku and Hida district visited by package tours from Taiwan.

\begin{tabular}{|c|c|}
\hline $\begin{array}{c}\text { Type of tourist destina- } \\
\text { tion }\end{array}$ & $\begin{array}{c}\text { Name of tourist destina- } \\
\text { tion }\end{array}$ \\
\hline $\begin{array}{c}\text { Tourist spots visited by } \\
\text { more than } 70 \% \text { of package } \\
\text { tours from Taiwan }\end{array}$ & $\begin{array}{c}\text { Kanazawa, Takaya- } \\
\text { ma, Shirakawago, } \\
\star \text { Nagoya* }\end{array}$ \\
\hline $\begin{array}{c}\text { Tourist spots visited by } \\
\text { more than } 50 \% \text { and less } \\
\text { than 70\% of package tours } \\
\text { from Taiwan }\end{array}$ & No tourist spots \\
\hline $\begin{array}{c}\text { Tourist spots visited by } \\
\text { more than } 30 \% \text { and less } \\
\text { than 50\% of package tours } \\
\text { from Taiwan }\end{array}$ & $\begin{array}{c}\Delta \text { alpine route of Tateya- } \\
\text { ma and Kurobe } \\
\text { shopping area at Chubu } \\
\text { international airport with } \\
\text { atmosphere of old } \\
\text { Japanese town* }\end{array}$ \\
\hline $\begin{array}{c}\text { Tourist place for appreci- } \\
\text { ating cherry blossom }\end{array}$ & $\begin{array}{c}\text { Nagoya* (in March) } \\
\text { Hokuriku and Hida dis- } \\
\text { trict (in latter half of April) }\end{array}$ \\
\hline
\end{tabular}

Symbols:

- traditional medium-sized or small town or village

$\star$ - large city with population of more than 1 million

$\triangle$ - natural beauty spots (including national parks)

* - tourist spot located outside Hokuriku and Hida district judging from the homepages of tourist companies in Taiwan, they were full before the earthquake, so the data have much value for a research into the preference of Taiwanese visitors. We investigated 52 package tours from Taiwan to the Hokuriku and Hida district sponsored by four major tourist companies in Taiwan and sold on the Internet. Those tours also included some destinations located outside the district, such as Nagoya, the third largest city in Japan (Fig.1).

The tourist companies are Southeast Tour, Ez Travel, Star Travel and Lion Travel. For the homepages of these companies (all in Chinese), see the References. For the location of the tourist spots, see Fig. 2.

Judging from Table 3, there are some very popular spots among tourists from Taiwan, such as Kanazawa, Takayama, and Shirakawago, which is a village famous for traditional houses included in the World Heritage List. Nagoya, the capital of Aichi Prefecture and the third largest city of Japan with a population of more than 2.2 million in 2010, is also visited as the gateway to the Hokuriku and Hida district and also as a shopping place represented by Sakae, the largest shopping area in the city. The high ratio of visitors to these tourist spots shows that the Hokuriku and Hida district has already set its position as one of the most popular tourist destinations in Japan for tourists from Taiwan. There are also other popular tourist places, such as the alpine route of Tateyama and Kurobe where tourists can cross the mountains by various vehicles such as bus, cable car and ropeway from the middle of April to the end of October. Also, tourists 
Table 4. Main tourist spots in the Hokuriku and Hida district visited by package tours from South Korea.

\begin{tabular}{|c|c|}
\hline $\begin{array}{c}\text { Type of tourist destina- } \\
\text { tions }\end{array}$ & $\begin{array}{c}\text { Name of tourist destina- } \\
\text { tions }\end{array}$ \\
\hline $\begin{array}{c}\text { Tourist spots visited by } \\
\text { more than } 70 \% \text { of package } \\
\text { tours from South Korea }\end{array}$ & No tourist spots \\
\hline $\begin{array}{c}\text { Tourist spots visited by } \\
\text { more than } 50 \% \text { and less } \\
\text { than } 70 \% \text { of package tours } \\
\text { from South Korea }\end{array}$ & $\star$ Khirakawago \\
\hline $\begin{array}{c}\text { Tourist spots visited by } \\
\text { more than } 30 \% \text { and less } \\
\text { than } 50 \% \text { of package tours } \\
\text { from South Korea }\end{array}$ & $\begin{array}{c}\star \text { Takayama } \\
\text { alpine route of Tateya- } \\
\text { ma and Kurobe } \\
\diamond \text { Kaga hot springs }\end{array}$ \\
\hline
\end{tabular}

Symbols:

- traditional medium-sized or small town or village

$\star$ - large city with population of more than 1 million

$\triangle$ - natural beauty spots (including national parks)

$\diamond$ - hot springs

* - tourist spot located outside the Hokuriku and Hida district

from Taiwan have an inclination to appreciate cherry blossom higher than tourists from other nations. This can be concluded from the fact that most of their package tours come at the best time for appreciating cherry blossom in the destinations they visit, for example Nagoya in March and the Hokuriku and Hida district in the latter half of April. And some tours even go to Kyoto or Osaka to appreciate cherry blossom more.

By contrast, only few package tours from South Korea visit the Hokuriku and Hida district, although they are the largest in terms of the number of foreign tourists visiting Japan. As in the case of package tours from Taiwan, we investigated 35 package tours from South Korea to the Hokuriku and Hida district by the homepages of major South Korean tourist companies. As Table 4 shows, the Hokuriku and Hida district is still not very popular with package tours from this country, because there are no tourist spots there visited by more than $70 \%$ of them. As for tourists from China, there are no group tours visiting the Hokuriku and Hida district at all, although they show the biggest increase in terms of numbers and are likely to become the largest group of visitors in the future.

The tourist companies are Hana Tour, Mode Tour and KAL Tour. For the homepages of these companies (all in Korean), see the References. For the location of the tourist spots, see Figure. 2.
On the other hand, the number of tourists from Europe visiting the Hokuriku and Hida district showed a similar increase as those from Taiwan. And we must consider that the total number of visitors from Europe is much smaller than those from Asian countries, such as South Korea and Taiwan (Tables 2 and 9). Still, the number of tourists from Europe to Takayama and Kanazawa, the most famous tourist destinations in the district, is almost equal to those from Asia except Taiwan and Hong Kong, as Tables 5 and 6 show.

Table 5. Number of foreign tourists visiting Takayama.

\begin{tabular}{|c|r|r|r|}
\hline Origin of tourists & \multicolumn{1}{|c|}{$\mathbf{1 9 9 9}$} & $\mathbf{2 0 0 4}$ & \multicolumn{1}{|c|}{$\mathbf{2 0 0 8}$} \\
\hline Asia & 14,213 & 32,519 & 101,812 \\
\hline Europe & 6,974 & 8,975 & 37,740 \\
\hline North America & 12,626 & 15,545 & 18,487 \\
\hline other & 6,467 & 3,870 & 13,441 \\
\hline Total & 40,280 & 60,909 & 17,1180 \\
\hline
\end{tabular}

Source: homepage of Takayama city.

The composition of tourists from major countries and areas in 2008 was as follows:

- Asia: Taiwan 60,334; Thailand 8,579; South Korea 6,832; Hong Kong 6,566; Singapore 5,044; China 2,176

- Europe: France 5,919; UK 5,691; Germany 4,269; Spain 4,009; Italy 3,485

- North America: USA 16,291.

We must not forget that Europeans have to buy more expensive air tickets and experience a much longer travel to visit Japan than tourists from such Asian countries as South Korea, Taiwan and China. Also, there is a great difference in per capita GDP between European countries and South Korea, Taiwan and Hong Kong.

Table 6. Number of foreign tourists visiting the Kenrokuen garden in Kanazawa.

\begin{tabular}{|c|r|r|r|r|}
\hline Origin of tourists & $\mathbf{2 0 0 2}$ & $\mathbf{2 0 0 5}$ & \multicolumn{1}{|c|}{$\mathbf{2 0 0 8}$} & \multicolumn{1}{c|}{$\mathbf{2 0 1 0}$} \\
\hline Asia & 15,755 & 61,086 & 116,437 & 100,240 \\
\hline Europe & 3,537 & 5,926 & 17,337 & 20,914 \\
\hline North America & 5,916 & 7,258 & 8,459 & 8,083 \\
\hline other & 1,269 & 1,565 & 4,277 & 4,772 \\
\hline Total & 26,177 & 75,835 & 146,510 & 134,009 \\
\hline
\end{tabular}

Source: data of the management office of the Kanazawa castle and the Kenrokuen garden (the most popular tourist spot in Kanazawa, see Photo 1).

The composition of tourists from major countries and areas in 2010 was as follows: 
- Asia: Taiwan 66,116; Hong Kong 11,284; South Korea 10,069; Singapore 4,902; China 3,959

- Europe: France 4,675; Spain 4,168; Italy 3,186; UK 1,961; Germany 1,834; Poland 432

- North America: USA 7,008.

To investigate why tourists from Taiwan and Europe appreciate the Hokuriku and Hida district while those from Asian countries except Taiwan do not, we used the data about preferences of foreign tourists by nationality and information from a local newspaper in the Hokuriku and Hida district, viz. the homepage of Hokkoku shimbun (a newspaper in the northern region). The newspaper's head office is located in Kanazawa and it sells mostly in the Hokuriku district delivering news about international tourism to Kanazawa, Ishikawa Prefecture and the Hokuriku district. We used the keyword analysis system of the newspaper to find past news about international tourism.

Table 7 shows preferences of foreign tourists by their nationality. It shows that while food is quite high on the expectation list of all visitors, there is much difference between the preferences of tourists from Asia and those from Europe or North America. The former come for shopping and hot springs, while the latter prefer tradition and the Japanese way of life. But strictly speaking, it is difficult to sum up all tourists from Asia in one word. It is true that those from Taiwan have much resemblance to those from South Korea or China in that they prefer shopping and hot springs. Visitors from Taiwan also prefer nature, just like those from China. But on the other hand, they have a stronger preference for the tradition of Japan and a weaker preference for its large cities. We can therefore say that the preferences of Taiwanese tourists are a mixture of those of visitors from Asia and western countries. And we can say that these preferences of the Taiwanese bear a strong relation to the fact that they are by far the largest group of foreign visitors to the Hokuriku and Hida district with its traditional medium-sized or small towns, beauty of nature, hot springs, and no cities with a population of more than one million.

Next we investigated whether or not our hypothesis was right by using the keyword analysis system of Hokkoku shimbun, and confirmed the rapid increase in foreign tourists, especially from Taiwan and European countries.

The increase in the inflow of tourists from Taiwan was mainly promoted by the increase in direct flights from Taiwan to Kanazawa, Toyama or Noto airports located in the north of Ishikawa Prefecture, especially since 2004 (Hokkoku shimbun 2006b). This was due to Kagaya, one of the most famous traditional hotels (called ryokan in Japanese), and Southeast Tour, the largest tourist company in Taiwan, making an alliance to invite more visitors from Taiwan and to introduce the Japanese culture of hot springs into Taiwan at the same time.

But we can say that a more essential key to the great success is the preference of tourists from Taiwan for medium-sized or small towns with the tradition of the good old days in Japan. It is clearly proved by the high proportion of them visiting Kanazawa and Takayama, which are considered the most attractive traditional cit-

Table 7. Preferences of foreign tourists by nationality (2010) (\%).

\begin{tabular}{|c|c|c|c|c|c|c|}
\hline Total & South Korea & Taiwan & China & $\begin{array}{l}\text { USA and } \\
\text { Canada }\end{array}$ & $\begin{array}{c}\text { UK, France } \\
\text { and Germany }\end{array}$ & $\begin{array}{l}\text { Italy and } \\
\text { Spain }\end{array}$ \\
\hline $\begin{array}{c}\text { food } \\
62.5\end{array}$ & $\begin{array}{r}\text { food } \\
53.1\end{array}$ & $\begin{array}{c}\text { nature } \\
64.4\end{array}$ & $\begin{array}{c}\text { nature } \\
63.6\end{array}$ & $\begin{array}{r}\text { food } \\
79.7\end{array}$ & $\begin{array}{r}\text { food } \\
81.6\end{array}$ & $\begin{array}{c}\text { tradition } \\
83.8\end{array}$ \\
\hline $\begin{array}{c}\text { shopping } \\
53.1\end{array}$ & $\begin{array}{c}\text { hot springs } \\
46.0\end{array}$ & $\begin{array}{r}\text { food } \\
62.3\end{array}$ & $\begin{array}{c}\text { shopping } \\
59.1\end{array}$ & $\begin{array}{c}\text { tradition } \\
73.8\end{array}$ & $\begin{array}{c}\text { tradition } \\
78.4\end{array}$ & $\begin{array}{r}\text { food } \\
76.9\end{array}$ \\
\hline $\begin{array}{l}\text { tradition } \\
\quad 45.8\end{array}$ & $\begin{array}{c}\text { shopping } \\
40.8\end{array}$ & $\begin{array}{c}\text { shopping } \\
56.7\end{array}$ & $\begin{array}{c}\text { hot springs } \\
51.3\end{array}$ & $\begin{array}{c}\text { Japanese way } \\
\text { of life } \\
55.7\end{array}$ & $\begin{array}{c}\text { Japanese way } \\
\text { of life } \\
59.0\end{array}$ & $\begin{array}{c}\text { Japanese way } \\
\text { of life } \\
56.0\end{array}$ \\
\hline $\begin{array}{c}\text { nature } \\
45.1\end{array}$ & $\begin{array}{l}\text { tradition } \\
35.6\end{array}$ & $\begin{array}{c}\text { hot springs } \\
49.4\end{array}$ & $\begin{array}{r}\text { food } \\
45.8\end{array}$ & $\begin{array}{c}\text { shopping } \\
54.8\end{array}$ & $\begin{array}{c}\text { large cities } \\
52.6\end{array}$ & \\
\hline $\begin{array}{c}\text { hot springs } \\
44.3\end{array}$ & $\begin{array}{c}\text { large cities } \\
31.1\end{array}$ & $\begin{array}{c}\text { tradition } \\
47.6\end{array}$ & $\begin{array}{c}\text { large cites } \\
39.1\end{array}$ & & & \\
\hline
\end{tabular}

Source: homepage of JNTO (Japan National Tourism Organization). Sample investigation at main international airports and ports in Japan (sample size 21,342). 


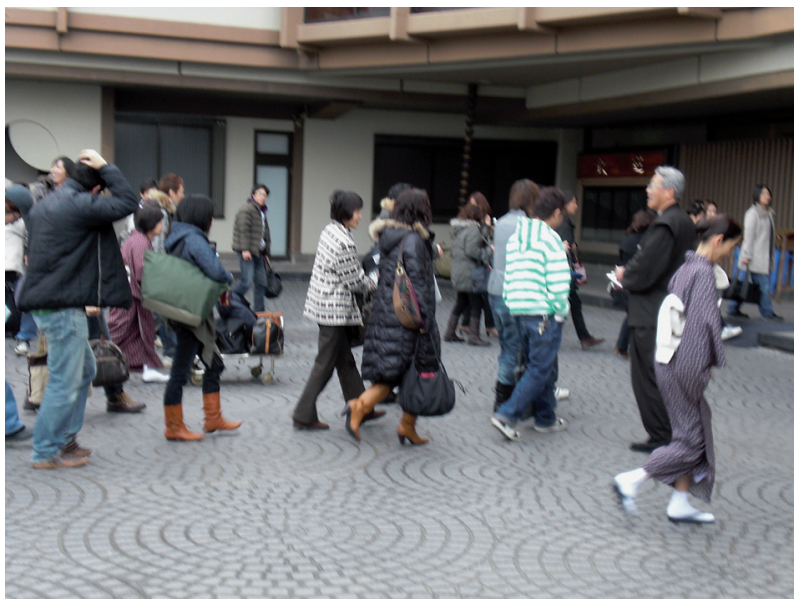

Photo 7. Tourists from Taiwan arriving at the entrance of the hotel Kagaya (2011).

All package tours were cancelled after the large earthquake that attacked Japan in March 2011, even though the Hokuriku and Hida district suffered no damage in it.

ies in Japan. Also, we cannot ignore the fact that the Taiwanese greatly appreciate the beauty of nature (Table 7). Cherry blossom in spring and heavy snow in winter are impossible to experience in Taiwan with its subtropical climate. But in Japan they can both be seen at the same time, especially in the latter half of April.

As to visitors from European countries, a rapid increase in their number began in the Hokuriku and Hida district in 2007, a little later than tourists from Taiwan. This was mainly due to the fact that some tourist spots in the Hokuriku district, such as the Kenrokuen garden in Kanazawa, the central area of Takayama city and the traditional houses in Shirakawago village, were listed as three-star tourist spots in the famous French Michelin guidebook (Hokkoku shimbun 2008). We can see this influence in the increase of foreign tourists visiting the Kenrokuen garden in Table 6 . The garden is the most popular tourist destination not only in Kanazawa, but in the entire Hokuriku and Hida district. For example, the number of European tourists visiting the garden in 2010 was almost equal to those from all Asian countries except Taiwan and Hong Kong. And the flow of tourists from Europe keeps increasing and changing the record (Hokkoku shimbun 2011). We can say that this tendency comes under the heading of preferences of those tourists for the tradition of Japan, as shown in Table 7. These tourist spots are also highly rated by guidebooks written in English. Tourists from Europe and
North America appreciate not only traditional buildings, but also many traditional handicrafts made in these cities, such as pottery and lacquer work described in those guidebooks. For example, more than $90 \%$ of gold leaf in Japan is produced in Kanazawa city.

On the basis of these analyses we can say that there is a close relationship between the preferences of foreign tourists by nationality and the tourist resource offered by the place they visit. In the case of the Hokuriku and Hida district, there are no large cities with a population of more than 1 million, and so tourists from South Korea and China do not have a very high opinion of it. But the tradition of Japan in medium-sized or small towns, the beauty of nature changing with the season, and hot springs are highly appreciated by visitors from Taiwan and Europe, which is reflected in their rapid increase in the recent years. The relation between the preferences of foreign tourists and the main tourist spots in the Hokuriku and Hida district is presented in Figure 2. The preferences of tourists from Europe and North America were assumed to be those suggested in the famous guidebooks, Michelin cartes et guides (2009) and Lonely Planet publications (2009). As to the ranking in Michelin cartes et guides (2009), which sometimes include several tourist spots with a different number of stars, we arranged the ranking by the tourist spots with the largest number of stars.

\section{The meaning of the rise of the Hokuriku and Hida district in international tourism to Japan}

As has been mentioned above, there is a new tendency in international tourism to Japan, namely a rapid increase in the number of visitors from Taiwan and Europe to the Hokuriku and Hida district seeking Japanese tradition and the atmosphere of good old days in medium-sized or small towns represented by Kanazawa and Takayama. Tourists from Taiwan also appreciate the beauty of nature as represented by cherry blossom and heavy snow.

In the recent decades, prefectures popular with foreign tourists visiting Japan are mainly of two types, as shown in Table 1. One includes 


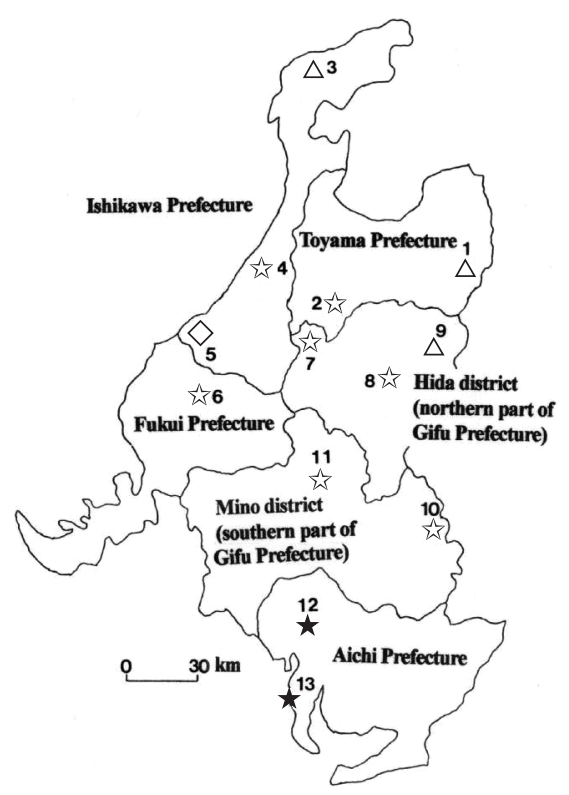

- traditional medium-sized or small town or village (including Buddhist temples)

$\star$ - large city with population of more than 1 million or shopping centre $\triangle$ - natural beauty spots (including national parks)

$$
\diamond \text { - hot springs }
$$

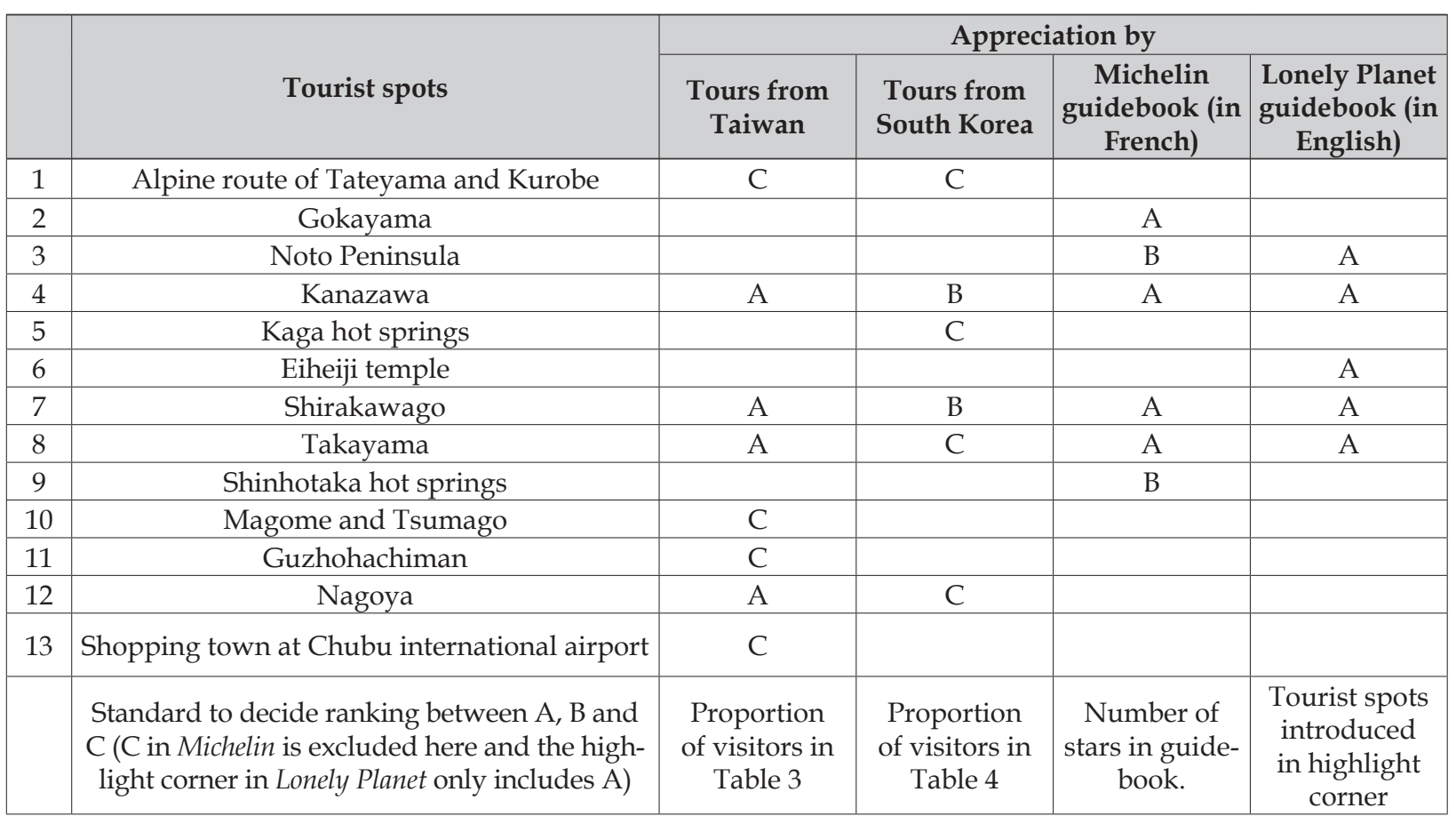

Fig. 2. Tourist spots in the Hokuriku and Hida district (including Aichi Prefecture and the southern part of Gifu Prefecture) and their evaluation by foreign tourists.

those with very famous tourist cities absorbing the largest number of foreign visitors from all over the world. Prefectures belonging to this type are Tokyo, Kyoto and Osaka. There are also other prefectures adjacent to them and ranking high in terms of the number of tourists, such as Kanagawa, Chiba, Hyogo and Nara. They also feature famous tourist spots, such as Tokyo Disneyland in Chiba Prefecture and Nara city in Nara Prefecture, which was the capital of Japan before Kyoto.
All these prefectures are located in the Kanto or Kinki district. As can be seen in Table 8, the proportion of tourists from Europe, North America and Australia to the Kanto and Kinki districts are a little higher than that the average for the whole of Japan.

The second type of prefectures are those located in the Kyushu and Hokkaido districts. Tourist spots located there are not so famous in the world as those in type 1 except Nagasaki city on which 
an atomic bomb was dropped in 1945. But there are various tourist attractions like a volcano, hot springs, and snowfields with a romantic atmosphere. These spots are especially popular with tourists from Asian countries, such as South Korea, Taiwan, China and Hong Kong. Also, there are regional cities with a population of more than 1 million, such as Fukuoka in the Kyushu district and Sapporo in the Hokkaido district (Fig. 1 ), which function as shopping places, especially for young tourists from those countries (Photos 8 and 9). Other prefectures of this type in Kyushu are Kumamoto and Oita with many hot springs. In the Kyushu and Hokkaido districts, the proportion of tourists from Asia is much higher than in Japan as a whole (Table 8).

With the prefectures of Toyama, Ishikawa and Gifu in the Hokuriku and Hida district improving their ranking remarkably in the recent years, we can say that this is a rise of a third type of prefecture in international tourism to Japan. It is true that there are no large cities attracting tourists from Asian countries like South Korea and China. Rather, this change has been promoted by tourists from Taiwan and Europe seeking the tradition of Japan in medium-sized or small town towns like Kanazawa and Takayama, or the beauty of nature represented by cherry blossom and snow in the mountains. In Table 8 , we can see that the prefectures in the Hokuriku and Hida district show a much higher proportion of tour-

Table 8. Nationalities of foreign tourists visiting Japan in $2010(\%)$.

\begin{tabular}{|c|c|c|c|}
\hline Prefecture or district & 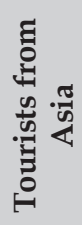 & 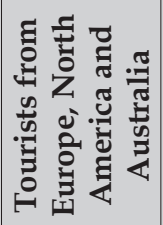 & 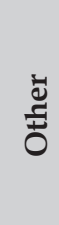 \\
\hline JAPAN & 70.8 & 27.8 & 1.4 \\
\hline Kanto district & 63.3 & 35.0 & 1.7 \\
\hline Kinki district & 65.5 & 32.9 & 1.5 \\
\hline Kyushu district & 80.4 & 18.7 & 1.0 \\
\hline Hokkaido district & 82.6 & 16.3 & 1.1 \\
\hline Toyama Prefecture & 89.4 & 10.3 & 0.3 \\
\hline Ishikawa Prefecture & 51.6 & 48.2 & 0.8 \\
\hline Fukui Prefecture & 54.0 & 44.0 & 2.0 \\
\hline Gifu Prefecture & 55.3 & 43.2 & 1.5 \\
\hline
\end{tabular}

Source: homepage of JNTO (Japan National Tourism Organization). Sample investigation at main international airports and ports in Japan (sample size 21,342).

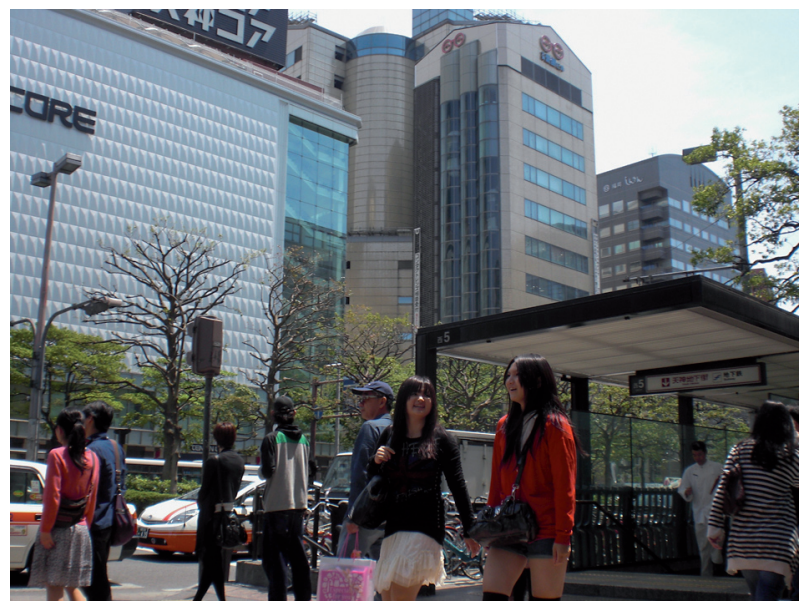

Photo 8. Department stores in Fukuoka city (Tenjin area).

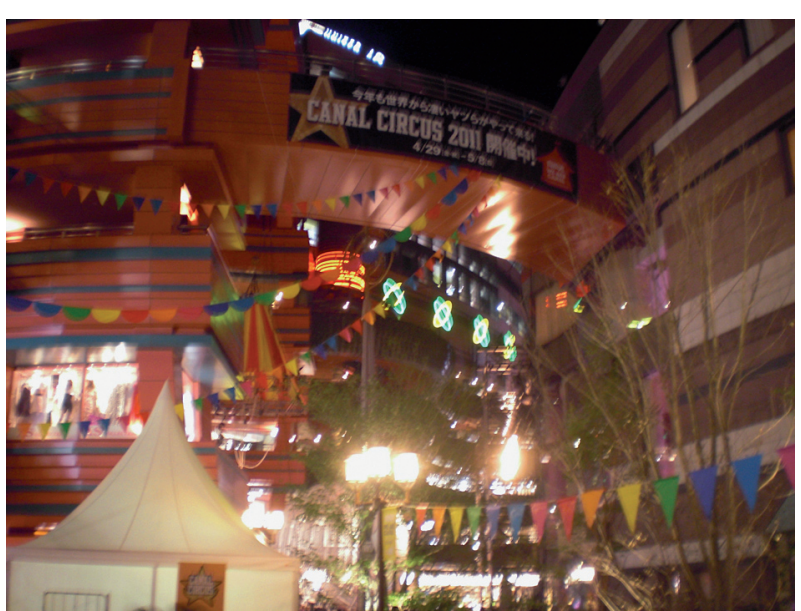

Photo 9. Canal city Hakata (shopping mall) in Fukuoka city.

ists from Europe, North America and Australia than the average for the whole of Japan, with the exception of Toyama Prefecture where most foreign tourists are those from Taiwan (Table 2). We must not forget that this change is caused by foreign tourists who are minorities in terms of numbers. For example, Europeans made up less than $10 \%$ of all foreign visitors to Japan in 2008 (Table 9). The Taiwanese are the second largest nationality of foreign tourists, but they may soon be outstripped by those from China, whose number has been growing the fastest in the recent years. But the important thing is that even districts in a local area without a large city can attract enough foreign tourists. Japan offers much variety in its districts, which makes it possible to accommodate foreign tourists with a wide range of preferences. 
Table 9. Number of foreign tourists visiting Japan by nationality (2008).

\begin{tabular}{|c|c|}
\hline Area or country & Number and \% of total \\
\hline Asia & $4,647,940(76.8)$ \\
\hline South Korea & $1,892,654(31.3)$ \\
\hline Taiwan & $1,264,425(20.9)$ \\
\hline China & $455,728(7.5)$ \\
\hline Hong Kong & $513,185(8.5)$ \\
\hline Europe & $521,133(8.6)$ \\
\hline North America & $627,726(10.4)$ \\
\hline USA & $474,137(10.2)$ \\
\hline Other & $251,882(4.2)$ \\
\hline Total & $6,048,681(100.0)$ \\
\hline
\end{tabular}

Source: homepage of JNTO (Japan National Tourism Organization).

\section{Conclusion}

We analysed a small but important structural change in international tourism to Japan expressed by a rapid increase in foreign tourists to the Hokuriku and Hida district located in the central part of the country, between the Sea of Japan and the Central Mountains, in terms of the relation between their preferences by nationality and the tourist resources offered in the destinations visited. Here there are no cities with a population of more than a million, unlike in the Kanto district with Tokyo or the Kinki district with Kyoto and Osaka. There are large cities even in such local areas as Kyushu and Hokkaido. But in the Hokuriku and Hida district there are many medium-sized or small towns preserving the tradition of Japan in the good old days and the beauty of nature represented by cherry blossom and snow. The increase in foreign visitors to the district is mainly due to those from Taiwan and Europe. Tourists from Taiwan have the common feature with those from other nations in Asia such as South Korea or China in that they prefer shopping and hot springs. But unlike those two nationalities, they are also much interested in Japanese tradition preserved in medium-sized or small towns rather than in large cities appreciated by tourists from South Korea or China. Their preference made them by far the largest group in the Hokuriku and Hida district.

Visitors from Europe began to increase mainly after 2007 when tourist spots in the district, such as Kanazawa, Takayama and Shirakawago, came to be highly appreciated by the famous French guidebook, Michelin. While Europeans make up less than $10 \%$ of all the foreign tourists visiting Japan, in the Hokuriku and Hida district they are the second largest group, almost equal in numbers to tourists from Asia, except Taiwan and Hong Kong, in spite of the very expensive fare and no direct flights from Europe.

These facts lead to two important conclusions. One is that foreign visitors can sometimes heighten the importance of a district in international tourism even if they are a minority in terms of numbers, like tourists from Europe to Japan. Another is that Japan has a sufficient variety of districts to attract tourists from different countries, and there is a close relationship between the preferences of tourists of a given nationality and the resources offered in the various districts.

Now the Japanese government is trying to invite more visitors and make international tourism into one of the country's most important industries. It is true that, economically, the most important group of tourists for Japan are those from Asia, who account for more than $75 \%$ of the total number of foreign visitors (Table 9) and spend a substantial amount of money on shopping, especially in large cities like Tokyo, Osaka or Fukuoka (Table 7). But we should not forget that cultural and historic values are also an important element of tourist resources, even if they are appreciated by visitors who are minorities in terms of numbers. The most important thing in developing international tourism to Japan is not getting more economic benefits, but focusing on a diversity of resources offered by the districts, thus attracting foreign tourists from different countries and catering to a great variety of their preferences.

\section{Acknowledgements}

I want to thank everyone working in the management office of the Kanazawa castle and the Kenrokuen garden for offering me the useful materials presented in Table 6. I also want to thank the many professors of geography from Spain, Italy, Switzerland, China and South Korea who gave me the chance to discuss international tourism at conferences of the IGU and sent me so warm-hearted emails after the disastrous 
earthquake and tsunami attacked the north-east coast of Japan on March 11, 2011. Finally, I want to thank the professors of Adam Mickiewicz University in Poland I have met at the IGU conferences in Hong Kong and other cities who have given me the honourable chance to write this article.

\section{References}

Hokkoku shimbun, 2006a. Gaikokujinkyaku Taiwan hoboissyoku the Hokuriku no Onsenchi cyuryusou ooku shinnichiteki Chugoku kaimu ni hitoshii (Almost all foreign tourists at hot springs in the Hokuriku district come from Taiwan. Most of them belong to the middle class and also feel much sympathy for Japan. But there are almost no tourists from China) (www.hokkoku.co.jp/_keizai/ K20060118001.htm; 18 January 2006).

Hokkoku shimbun, 2006b. Toyama Kukouga nobiritsu zenkoku ichii sakunen no gaikokuzinkyaku raihou matome Taiwan kankoukyaku ga atooshi (Toyama airport showed the highest ratio of increase in the number of visiting foreign tourists last year - pushed by tourists from Taiwan). (www.hokkoku.co.jp/_keizai/ K20060418003.htm; 18 April 2006).

Hokkoku shimbun, 2008. Kenrouen mitsuboshi Michelin Nihonban kankouchi guide Furancejin kankoukyaku 4 warizou (Kenrouen was listed as a three-star tourist spot in Michelin, and tourist traffic from France saw a 40\% increase) (www.hokkou.co.jp/_today/H20080226101.htm; 26 February 2008).

Hokkoku shimbun, 2011. Oushu ninki kencho tuzuku sakunen no Kenrokuen kankoukyaku gokakoku de kako saita (The popularity among tourists from Europe continues - the number of tourist visiting Kenrokuen changed the record in tourists from five European countries) (www. hokkoku.co.jp/subpage/ H20110107102.htm; 7 January 2011).
JNTO, 2009. JNTO hounici gaikyaku houmonchi chosa 2007/2008 (JNTO research on the destinations of foreign guests visiting Japan in 2007 and 2008), JNTO, Tokyo.

Kanda K. (ed.), 2009. Kankou no kukan - shiten to approach (The space of tourism - focus and approach). Nakanishiya, Kyoto, Japan.

Lonely Planet Japan, 2009. Lonely Planet Publications, Footscray, Australia.

Matsumura Y., 2009. Osaka guest house chiiki o souzousuru kokoromi (The trial for creating a guesthouse area in Osaka). In: Kanda K. (ed.), Kankou no kukan - shiten to approach. Nakanishiya, Kyoto, Japan.

Le guide vert Japon (The green guide Japan), 2009. Michelin Cartes et Guides, Paris, France.

Ohyabu T. \& Ohuchi A. (eds), 2008. Hokutou Asia kankou no choryu (The stream of tourism in North-East Asia). Kaibundo, Tokyo, Japan.

Shimizu I., 2007. Chugokujin no hounichi ryokou no keitai to sono henka - kankou kara tourism he (Changes in the patterns of Chinese tourism to Japan - from kankou to tourism). Chirigaku ronsyu (Geographical Studies), 82: $37-52$.

\section{Homepages used as reference}

Ez Travel (Taiwan, in Chinese) www.eztravel.com.tw Hana Tour (South Korea, in Korean) www.hanatour.com Hokkoku shimbun (Japan, in Japanese) www.hokkoku.co.jp JNTO (Japan National Tourism Organization, Japan, in Japanese) www.jnto.go.jp

KAL Tour (South Korea, in Korean) www.kaltour.com Lion Travel (Taiwan, in Chinese) www.liontravel.com Mode Tour (South Korea, in Korean) www.modetour.com Southeast Tour (Taiwan, in Chinese) www.settour.com.tw Star Travel (Taiwan, in Chinese) www.startravel.com.tw Takayama city (Japan, in Japanese) www.city.takayama. lg.jp/kankou/index.htm 